\title{
The Innovation of College English Teaching under the Mechanism of Cultivating Practical Talents
}

\author{
Li Wangting \\ School of Foreign Studies, Xi'an University 710061
}

Keywords: Practical Talents; Training Mechanism; College English; Innovation

Abstract: After years of development, English teaching in colleges and universities of our country has achieved good results in many aspects. But we must see that in the new era of economic and social development, the training of personnel puts forward higher requirements and higher standards. It is urgent to deepen the reform of English teaching in colleges and universities by making self-adjustment and consciously guiding with the aim of cultivating talents. This paper briefly expounds and analyzes the innovation of college English teaching under the practical talents training mechanism.

China has always attached great importance in English teaching Especially since the reform and opening up,English has been regarded as an important public and basic course in China's colleges and universities.After years of development and reform,China's College English teaching has achieved good results. With the economic development and social progress, however,China's demand for talent has changed substantially.As a professional personnel training institution,colleges and universities are bound to make corresponding adjustments to this change.

\section{The concept of practical talents}

What is practical talent?Many educators hold different views on this issue.But on one point,their views are consistent.That is,the talent trained by our higher education system should be close to the needs of society,enterprise,market.English itself is a very practical and strong course,but due to the disadvantages of traditional education and teaching,our higher English teaching has made remarkable achievements in theory when it comes to practical applications,they are woefully inadequate.Many scholars have followed and studied this phenomenon for a long time,carrying out bold reform and innovation both in theory and practice Many new models of education and teaching are put forward,one of which is the reform of training mode dominated by practical talents.

After China's reform and opening up,especially after China's accession to the WTO,China's economy has been fully integrated into the overall pattern of the world economy.Under the current wave of economic globalization,it is impossible for any country to achieve long-term development in a closed environment. Now more and more enterprises go abroad and actively participate in the market competition.Against this backdrop,the demand for high-quality,specialized English speakers is surging.Every year,a large number of English majors enter the society,and it is an An indisputable fact that many students can not find jobs.On the one hand, there is an urgent demand for talents,on the other hand,a large number of English majors can not find jobs.This phenomenon seems 
contradictory, but it has deep roots One of the most important reasons for this is that there is a serious disconnect between our approach to talent development and the direction of talent demand.Many students graduate from school with excellent grades,but once they start working,they realize that English is for use,not for examination.Many students are also very confused that why schools inside the training mode,assessment mode and social,and the existence of the employing unit is very different.This is a social phenomenon worthy of in-depth study, an educational phenomenon.

\section{Analysis of the reasons for the lack of training of practical talents.}

The demand for such a strong social demand for practical talents,then what causes the lag in training of practical talents?This is a complex issue that can not be fully explained in a word or two.But generally speaking,the lack of practical talents training in China's universities can be attributed to the following reasons:

\subsection{The concept of personnel training is backward}

For a long time,there has been a big deviation in our understanding of the cultivation of college English talents,and the concept of personnel training is behind. When we look at a student,we look only at the student's current situation,and rarely at the student's future social development and personal prospects. Many people even think of English simply as a foreign subject,without equating it with social and interpersonal communication.It is true that English itself has the attribute of knowledge,but the social attribute and communicative attribute of English are the essential attribute of English.Colleges and universities should be a convergence of the most cutting-edge teaching ideas and the latest information platform,but China's university platform rarely has an open mind.Many of US still follow the traditional model of teaching in colleges and universities, where the teacher is the center and the students are the audience.In the curriculum teacher speaks blindly,the student imitates blindly and studies.This educational teaching method has become the biggest obstacle to the development of discipline construction.It is hard to imagine that in such a mode of education and teaching, our goal of talent cultivation can be smoothly realized.It is difficult to arouse students' enthusiasm and interest in learning,and even counterproductive in some cases.The traditional mode of education and teaching in many places still have great room for survival,the existence of this phenomenon should first from our ideological roots to find the reason.

\subsection{The overall quality of teachers is not high}

Teachers are the organizers and implementers of education and teaching.Does the current overall quality of our college English teachers correspond to the requirements of the teaching tasks?Is it compatible with the goal of talent training?This is a question we should ask ourselves.Many of our college English teachers have made great achievements in English majors,but English is a complicated social science.English learning includes not only the knowledge of English itself,but also the social knowledge,humanistic knowledge,communicative knowledge and so on. Whether our teacher quality can undertake such education teaching request?The answer to that question is obvious.At present,the problem of the overall low quality of college English Teachers has become a prominent problem to be solved in the course construction of college English.In addition,many of our college English teachers have strong professional knowledge,but lack of teaching skills,they are full of knowledge,but feel unable to perform in teaching.The reason is that many of our college English teachers are graduates of English majors. They are not from a normal university. They have no practical experience on how to carry out education and teaching,but only have a cavity 
enthusiasm and talent.

It is also a prominent problem that the post-training of college English teachers can not be effectively guaranteed. Whether it is professional knowledge or the concept of education and teaching is a constantly changing thing.A lot of people actually see them as unchanged.Some colleges and universities attach great importance to this issue,and there is a supporting mechanism for teachers to learn and train in the latter stage,so that teachers can be constantly upgraded and improved in their study and communication,but in this point.most colleges and universities have obvious loopholes Some teachers have not had such opportunities since they started to work. Their ability and quality are basically at the same level.The existence of this problem has even discouraged the enthusiasm and initiative of teachers in their work They think their development space is limited,the psychology unavoidably produces the slack and the weary mood.

\subsection{Lack of information application}

With the rapid development of information technology,various teaching methods based on information have come into our field of vision.This is especially true in science and engineering.However,the application of information technology in liberal arts courses,especially in college English courses,is obviously backward.For example,micro-courses, MOOCs and other English Learning Teaching AIDS in many colleges and universities in the English curriculum has not been widely promoted and applied.As far as I know, most of the college English teaching is still in the multimedia era,and this multimedia system is also relatively simple,that is,slides.How does this level of information guarantee the effectiveness of our education and teaching if students learn effectively outside the classroom?The low level of information technology has become a common problem in college English teaching.

The reason why such a problem occurs,I think our teachers have a lot to do with the teaching.College English teachers are generally liberal arts graduates,and they are not familiar with the computer,network technology,etc.In fact,there are other ways to solve this problem,such as involving students in courseware making.If the problem of low level of information technology can not be solved scientifically and effectively,it is difficult for college English teaching to make a substantial breakthrough either in classroom teaching capacity or in students' extensive learning after class.Breaking the shackles of the traditional teaching model should not only be a slogan,but should really be implemented into our actual actions.

\section{Innovative Approaches to college English teaching under the mechanism of culltivating practical talents}

The author believes that the innovation of college English teaching under the practical talent cultivation mechanism should focus on the following aspects:

\subsection{Change the concept of education and teaching}

We want to cultivate practical English talents.First of all,we should have a clear understanding of the current requirements and objectives of talent training. What is practical talent?how to train practical talent?This kind of training is a scientific system work,can night,and can not be achieved through the transformation of a link.Therefore,we must take the advanced talented person training idea as the instruction,both must be cautious,and must be committed to the reform. 


\subsection{Introduce humanistic education into teaching}

College English should not be an isolated course. We should pay enough attention to the lack of humanistic education in traditional college English teaching.Humanistic factors are closely related to English teaching.Humanistic learning has an imperceptible promoting effect on English learning.The relationship between the two needs no further elaboration here.Through the study and understanding of the humanities,students will have a comprehensive grasp of the knowledge they have learned in English.The more they understand the cultural background of English,in the future in the actual application of English process can be more handy,not to occur some low-level application errors.At present,this problem has been taken seriously in some colleges and universities,and they have set up a complete set of English culture courses.In terms of the educational and teaching results achieved, it is very ideal.How to popularize such education and teaching in the later period, each school should proceed from its own reality and work out practical methods.

\subsection{Change the traditional teaching model}

Efficient English teaching should not be a boring course,but because of the influence of the traditional teaching model,we are always unwilling to break away from the blackboard chalk thinking,unwilling to develop new educational teaching methods,only then causes the university English teaching the reform to move difficultly.We should be good at using new scientific and technological means,be bold in innovation and bold in practice.Young students themselves hold a lot of enthusiasm for new things,novel teaching methods are very easy to stimulate their interest and enthusiasm for learning.At the same time,we must break the traditional English teaching evaluation system.At present,our examination system and evaluation system can not meet the needs of English teaching.This examination system is designed for examination-oriented education,which is neither reasonable nor scientific.The assessment system of settling into residence is easy to be misleading to student's study,its influence is very negative.The reform of the traditional assessment system should involve a wide range of teachers and students.

\section{Conclusion}

At present, the reform of college English teaching in China has stepped into the deep-water area It is a historical task for every educator to do well the innovative work of college English teaching which takes practical talents training as the leading direction. We should proceed from the teaching practice and carry out corresponding exploration in theory and practice to promote the healthy development of college English teaching reform.

\section{References}

[1] He Chunyan. Construction of college English classroom teaching in Independent College [J].Journal of Scientific Instruction, 2013(7)

[2] Ma Xiaoting.Problems and reform in college English Teaching [J] Journal of Qinghai Teachers College, 2004(6)

[3] Chen Hongbo.College English Teaching Reform Aiming at Training Applied Talents [J] Tech Vision 2015(32)

[4] Gao Yunxia.On the reform of English teaching under the training mode of Applied Talents [J]Contemporary Educational Practice and teaching research,2015(11)

[5] Kong Qingyan, Liu Hongzhang. Knowledge and practice of practical English teaching reform in Higher Vocational Colleges [J] China Foreign Language, 2005

[6] Wang Huizhao. Artificial target language environment and English learning effectiveness [J] China Foreign Language, 2005,(3). 